\title{
Pengembangan Bahan Ajar Berbasis Pendidikan
} Matematika Realistik Indonesia (PMRI) untuk Mendukung Kemampuan Pemecahan Masalah Operasi Hitung Pecahan

\author{
Ahyansyah $^{1}$, Cholis Sa'dijah ${ }^{2}$, Abd. Qohar ${ }^{2}$ \\ ${ }^{1}$ Pendidikan Dasar-Universitas Negeri Malang \\ ${ }^{2}$ Pendidikan Matematika-Universitas Negeri Malang
}

\begin{tabular}{l}
\hline \hline INFO ARTIKEL \\
\hline Riwayat Artikel: \\
Diterima: $14-05-2020$ \\
Disetujui: $20-12-2020$ \\
\hline
\end{tabular}

Kata kunci:

teaching materials;

Indonesian realistic mathematics

education;

problem solving skill;

bahan ajar;

pendidikan matematika realistik

indonesia;

kemampuan pemecahan masalah

\begin{abstract}
ABSTRAK
Abstract: This research and development was aimed to produce teacing materials supporting the process of learning mathematics based on Indonesian realistic mathematics education (PMRI) to support the mathematical problem solving skills of fraction counting operations that meet valid and practical criteria. This research and development uses Plomp Model which three steps namely (1) preliminary research, (2) prototype phase, (3) assessment. The results show that the validity test results of teaching materials have met the valid criteria with a percentage of $83.7 \%$. Meanwhile, the practical test results of teaching materials meet very practical criteria with a percentage of $90.2 \%$.
\end{abstract}

\begin{abstract}
Abstrak: Tujuan dari penelitian dan pengembangan ini untuk menghasilkan bahan ajar sebagai pendukung proses pembelajaran matematika berbasis Pendidikan Matematika Realistik Indonesia (PMRI) untuk mendukung kemampuan pemecahan masalah operasi hitung pecahan yang valid dan praktis. Model pengembangan yang digunakan adalah Plomp yang terdiri atas tiga langkah, yakni (1) tahap penelitian awal (preliminary research), (2) tahap pengembangan protitipe (prototipye phase), dan (3) tahap penilaiain (assessment phase). Hasil penelitian dan pengembangan menunjukkan bahwa hasil uji kevalidan bahan ajar telah memenuhi kriteria valid dengan persentase sebesar $83,7 \%$. Hasil uji kepraktisan bahan ajar memenuhi kriteria sangat praktis dengan persentase sebesar $90,2 \%$.
\end{abstract}

\section{Alamat Korespondensi:}

\author{
Ahyansyah \\ Pendidikan Dasar \\ Universitas Negeri Malang \\ Jalan Semarang 5 Malang \\ E-mail: ahyansyah.1821038@ students.um.ac.id
}

Salah satu tujuan pembelajaran matematika dalam kurikulum 2013 adalah pemecahan masalah. Menurut NCTM bahwa masalah matematika yang dipelajari kelas $\mathrm{V}$ diharapkan dapat dipecahkan dalam konteks lain, memilih dan menggunakan beberapa strategi pemecahan masalah dan meninjau kembali masalah yang diberikan. Sejalan dengan pendapat NCTM, pemecahan masalah matematika dalam kurikulum 2013 dikemas dalam pendekatan saintifik dan model pembelajaran seperti model pembelajaran berbasis proyek dan model pembelajaran berbasis masalah (Sa'dijah, Yuwono, \& Anwar, 2013). Oleh sebab itu, pemecahan masalah matematika di sekolah dasar dapat dimulai dari memberikan konteks permasalahan matematika yang sederhana sampai konteks permasalahan yang kompleks (Sa'dijah, Yuwono, \& Anwar, 2013). Selain itu, Sa'dijah, Sa'diyah, Sisworo, \& Anwar (2020) kemampuan pemecahan masalah yang dimiliki oleh siswa akan mampu mengembangkan kemampuan berpikir tingkat tinggi dalam menyelesaikan permasalah kehidupan. Mengingat pentingnya pemecahan masalah, OECD menjadikannya salah satu indikator dalam setiap kompetisi matematika internasional sehingga siswa perlu dibekali kemampuan pemecahan masalah yang baik sejak sekolah dasar dengan memperhatikan perbedaan gaya belajar yang dimilikinya (Ahyansyah, 2019).

Salah satu kompetisi matematika internasional yang menjadikan kemampuan pemecahan masalah matematika adalah Program International for Student Assesment (PISA). Salah satu penilaiannya adalah kemampuan matematika dalam literasi melalui pengerjaan soal berbasis pemecahan masalah yang dilaksanakan tiga tahun sekali oleh OECD (Stacey, 2010; Wilkens, 2011). Pemecahan masalah dalam literasi matematika adalah kemampuan untuk mengetahui, mengidentifikasi, menerapkan pengetahuan matematika dalam kehidupan (Ojose, 2011; Hasnawati, 2016). Menurut OECD dalam (PISA, 2015) mendefinisikan bahwa pemecahan masalah adalah kemampuan siswa dalam merumuskan, menerapkan dan menerjemahkan konsep, prinsip, prosedur, dan fakta dalam matematika. Kemampuan pemecahan masalah matematika yang memuat fakta, 
konsep, prinsip, dan prosedur tersebut digunakan untuk mendeskripsikan, menjelaskan, dan memprediksi fenomena membutuhkan suatu komponen untuk mendukung keberhasilan proses pembelajaran, yakni penggunaan bahan ajar.

Salah satu komponen yang mendukung proses pembelajaran adalah bahan ajar. Bahan ajar akan mampu membuat siswa lebih tertarik didalam kelas, menjadi lebih aktif dalam diskusi, melakukan lebih banyak latihan soal sesuai dengan kualitas individu belajar, mengalami pembelajaran nyata, mendapatkan kesempatan untuk berkolaborasi, berpikir kritis, dan meningkatkan pemecahan masalah (Koparan, 2017). Bahan ajar dalam pembelajaran matematika merupakan bahan konkret yang digunakan dalam membantu siswa membentuk pemahaman yang jelas tentang konsep matematika dan tidak hanya memfasilitasi siswa dalam mempelajari subjek, tetapi juga membantu para guru dalam mengajarkan matematika (Ulandari, Amry, \& Saragih, 2019). Waluyo, Sa'dijah, \& Subanji (2016) memaparkan bahwa untuk mengorganisir konsep matematika yang akan dipelajari siswa maupun yang sudah dipelajari siswa agar setiap siswa mempunyai seperangkat pengetahuan yang tersistematis diperlukan perangkat yang disebut bahan ajar. Bahan ajar digunakan sebagai penunjang pembelajaran di kelas, menuntut siswa untuk aktif dalam pembelajaran sehingga pembelajaran akan lebih berpusat pada siswa dan seluruh kegiatan dapat dilaksanakan dengan optimal dan siswa terlibat aktif (Manopo, Sudirman, \& Sulandra, 2018). Khusna, Yuwono, \& Muksar (2016) bahwa bahan ajar matematika memengaruhi penalaran matematis siswa melalui beberapa aktivitas belajar dan memperdalam pemahaman siswa pada materi yang disajikan.

Hasil tes PISA tahun 2015 menunjukkan bahwa kemampuan pemecahan masalah matematika siswa Indonesia dalam uji literasi matematika mendapatkan peringkat kategori rendah dibawah 450 standar PISA dengan nilai 395,3 (PISA, 2015). Sedangkan dalam uji TIMSS tahun 2015 memperoleh posisi urutan bawah dengan skor matematika 397 (TIMSS, 2015). Mahdiansyah \& Rahmawati (2014) menggambarkan bahwa perbedaan kategori dan karakteristik sekolah memengaruhi kemampuan pemecahan masalah siswa dalam uji literasi matematika. Data Puspendik Kemendikbud (2019) menunjukan bahwa sebesar 77, 13\% kemampuan pemecahan masalah matematika siswa masih tergolong rendah. Sementara itu, data kemampuan matematika siswa di Jawa Timur berada pada kategori kurang sebesar 71,35\%. Berdasarkan data tersebut menunjukan bahwa kemampuan pemecahan masalah matematika siswa di Indonesia umum masih rendah.

Studi pendahuluan dilakukan di SDN Sukoharjo 1 pada hari Senin, 4 November 2019, SDN Sukoharjo 2 pada hari Rabu, 6 November 2019 dan SDN Kotalama pada hari Jum'at, 8 November 2019 melalui kegiatan wawancara dengan guru kelas, wawancara dengan kepala sekolah, pengamatan langsung pembelajaran di kelas, telaah dokumen bahan ajar dan tes soal pemecahan masalah matematika. Hasil studi pendahuluan melalui pengamatan langsung proses pembelajaran dan wawancara tidak terstruktur bersama guru kelas V dan wawancara dengan kepala sekolah didapatkan informasi bahwa secara umum ketiga sekolah tersebut memiliki karakteristik yang sama. Hasil wawancara didapatkan informasi bahwa di Kota Malang terdapat enam kategori peringkat sekolah yang dibagi menjadi tiga bagian, yakni peringkat tinggi atau peringkat 1 dan 2 , peringkat sedang atau peringkat 3 dan 4, dan peringkat rendah atau peringkat 5 dan 6 . Berdasarkan kategori tersebut bahwa SDN Sukoharjo 1, SDN Sukoharjo 2, dan SDN Kotalama 6 Kota Malang masuk dalam kategori sedang dengan peringkat ketiga dan keempat. Peringkat ini dinilai berdasarkan perolehan nilai ujian nasional dan hasil penilaian dari pengawas sekolah.

Selanjutnya, kegiatan telaah dokumen. Hasil telaah dokumen didapatkan informasi bahwa bahan ajar yang digunakan oleh siswa kelas V adalah bahan ajar yang berasal dari pemerintahan pusat berdasarkan keputusan pemerintah (kemendikbud). Menurut Lilik Suryani, S. Pd sebagai guru kelas dan Dra. Heriyani, M.M sebagai kepala SDN Sukoharjo 2 Kota Malang mengungkapkan bahwa penggunaan bahan ajar bukan hanya digunakan ditiga sekolah tersebut, tetapi digunakan oleh semua sekolah yang ada di Kota Malang. Selain buku dari keputusan pemerintah, terdapat juga bahan ajar berupa modul pengayaan pembelajaran matematika yang disusun oleh tim guru dari Dinas Kota Malang. Bahan ajar yang digunakan oleh sekolah di Kota Malang berdasarkan keputusan pemerintah, sebagaimana ditunjukan pada gambar 1, 2, dan 3.

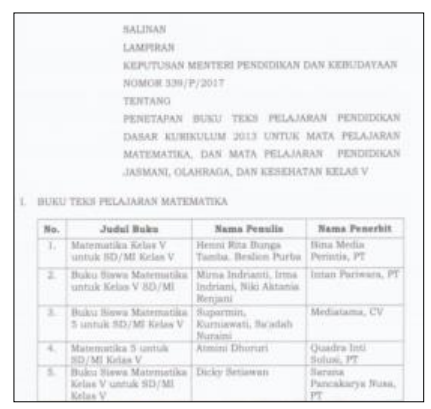

Gambar 1.

Salinan Keputusan Kemendikbud Tentang Penggunaan Buku Teks Pelajaran Matematika

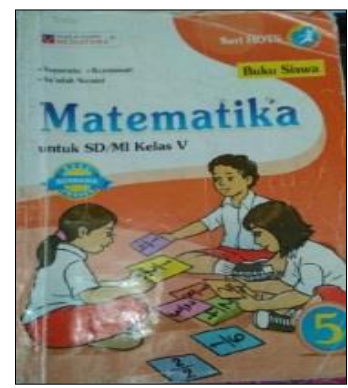

Gambar 2.

Buku Tes Pelajaran Matematika dari Kemendikbud

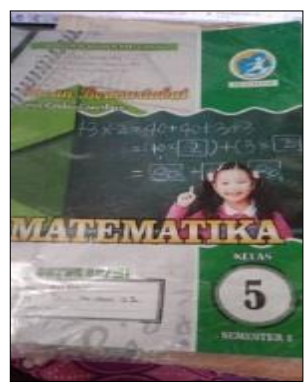

Gambar 3.

Modul Pengayaan Pembelajaran Matematika dari Dinas Kota Malang 
Hasil analisis bahan ajar didapatkan informasi bahwa bahan ajar memiliki beberapa kelemahan. Pertama, dilihat dari aspek materi bahwa bahan ajar memiliki beberapa kekurangan, seperti (a) ketidaksesuain materi yang disusun dengan stabdar kompetensi yang ditentukan dalam kurikum; (b) materi pelajaran yang disusun masih kurang mendalam; (c) masih kurang aktivitas siswa secara berkelompok, aktivitas mengomunikasikan dan aktivitas menyimpulkan materi secara bersama sesuai dengan tuntutan pendekatan saintifik dalam kurikulum 2013; (d) masih kurang memasukkan masalah konstekstual sehingga pembelajaran masih kurang bermakna bagi siswa seperti pada materi operasi perkalian dan pembagian pecahan; (d) materi pecahan merupakan materi yang masih banyak kekurangan dari aspek kedalaman dan keluasaan materi. Kedua, dilihat dari aspek kebahasaan bahwa (a) penggunaan kalimat dalam paragraf belum sesuai dengan tingkat perkembangan dan pemahaman siswa sehingga menyebabkan kesulitan siswa dalam memahami konsep materi pembelajaran; (b) masih terdapat beberapa ilustrasi yang panjang serta gambar yang belum jelas. Ketiga, dilihat dari aspek penyajian materi bahwa (a) materi yang disajikan belum runtut dan sulit dipahami oleh siswa sehingga menyebabkan keutuhan makna dari materi belum tersampaikan; (b) penyajian materi belum dapat mendukung kemampuan pemecahan masalah dan berpikir kreatif sesuai tingkat perkembangan siswa; (c) masih kurang mengandung wawasan kontekstual sesuai dengan ragam budaya dan karaktersitik Indonesia dan mendorong siswa menemukan sendiri makna materi untuk diterapkan dalam kehidupan keseharian. Keempat, dilihat dari aspek kegrafikan bahwa bahan ajar (a) ukuran dan jenis huruf yang digunakan belum sesuai dengan usia dan karakteristik siswa; (b) belum menggunakan ilustrasi yang memperjelas pesan yang disampaikan; (c) tampilan warna pada gambar yang digunakan masih belum jelas. Selanjutnya, pada gambar adalah salah satu hasil tes soal pemecahan masalah siswa materi pecahan.

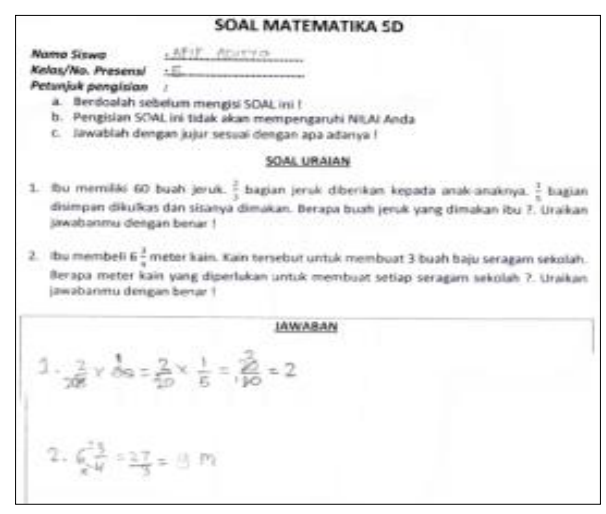

Gambar 4. Jawaban Siswa

Soal pemecahan masalah adalah soal terbuka (closed task) materi operasi hitung pecahan. Berdasarkan gambar 4 didapatkan informasi bahwa siswa belum mampu memahami masalah yang diberikan sehingga tidak mampu menentukan strategi pemecahan masalah yang akan digunakan. Hal ini menyebabkan siswa tidak dapat menyelesaikan dan menentukan kembali jawaban sesuai masalah yang diberikan. Hal ini disebabkan siswa jarang dilatih untuk menyelesaikan soal cerita pemecahan masalah. Walaupun dalam bahan ajar yang digunakan sudah terdapat soal-soal pemecahan masalah kategori soal HOTS. Namun, soal pemecahan masalah tersebut belum tepat diberikan kepada siswa usia sekolah dasar. Selain iut, kegiatankegiatan pembelajaran pada bahan ajar juga belum mendukung kemampuan pemecahan masalah matematika siswa. Hasil di atas menunjukan bahwa rendahnya kemampuan pemecahan masalah matematika siswa, salah satunya disebabkan oleh bahan ajar.

Berdasarkan permasalahan di atas, penggunaan bahan ajar menggunakan pendekatan pembelajaran Pendidikan Matematika Realistik Indonesia (PMRI) adalah satu solusi untuk mengatasi rendahnya kemamampuan pemecahan masalah matematika siswa. PMRI diadaptasi dan dikembangkan dari pendekatan RME di Belanda dan beberapa negara lain, seperti Amerika Serikat dan dijadikan suatu pendekatan pembelajaran. Pembelajaran Realistic Mathematic Education (RME) di Indonesia disebut PMRI yang disesuaikan dengan konteks dan budaya di Indonesia (Sembiring, 2010). Melalui PMRI, siswa akan memiliki daya tangkap tinggi artinya permasalahan matematika dapat diungkapkan oleh siswa secara jelas dengan bahasa yang mudah (Soedjadi, 2014; Sembiring, 2010). Bahan ajar pendidikan matematika realisik dapat meningkatkan kemampuan pemecahan masalah matematika karena ada aktivitas menafsirkan masalah yang berangkat dari lingkungan kehidupan siswa (Maulydia, Surya, \& Syahputra, 2017; Hasibuan, Saragih, \& Amry, 2018). Siswa dapat mengungkapkan beragam ide dengan lancar dan benar, menggunakan berbagai strategi yang berbeda-beda, memiliki kemampuan menggunakan strategi dan pendekatan yang berbeda dari yang lain dalam menyelesaikan masalah melalui PMRI (Sembiring, 2010). Oleh sebab itu, masalah yang digunakan dapat juga dari dunia fantasi dongeng, dunia formal matematika yang dapat dibayangkan dalam pikiran siswa (Heuvel-panhuizen, dkk., 2014). 
Bahan ajar bermuatan pendidikan matematika realisitik harus memuat dan disesuikan dengan kurikulum yang berlaku. Bahwa bahan ajar berbasis realisitik matematika harus disesuaikan dengan kurikulum dan karakteristik siswa di sekolah (Ubaidillah, Subanji, \& Sa'dijah, 2014); (Asih, Irawan, \& Sa'dijah, 2018). Selain itu, (Sembiring, 2010) juga mempertegas bahwa bahan ajar dengan pendekatan PMRI perlu memenuhi standar, yakni (1) bahan ajar disesuaikan dengan kurikulum; (2) permasalahan realistik untuk mendukung kemampuan pemecahan masalah matematika; (3) memuat konsep matematika yang saling terkait agar pembelajaran menjadi bermakna; dan (4) materi yang disusun dalam bahan ajar dapat memfasilitasi perbedaan kemampuan siswa.

Banyak penelitian yang hanya meneliti tentang bahan ajar RME untuk kemampuan berpikir kritis, kemampuan komunikasi, kemampuan berpikir kritis, kemandirian belajar dan literasi matematika siswa yang mengambil subyek uji coba di SMP dan SMA yang secara teori bahwa usia anak SMP dan SMA sedang mengalami proses transisi dari konkrit ke abstrak. Terdapat penelitian yang hanya meneliti sebatas pengaruh dan penerapan dari pendekatan RME, dan masih secara umum menggunakan karakterisitik RME yang dikembangkan oleh Belanda. Akan tetapi, masih kurang yang menggunakan PMRI, masih kurang menciptakan produk berupa buku siswa yang disertakan buku guru berbasis PMRI dan mengedapankan konteks budaya Indonesia. Selain itu, bahan ajar yang disusun memuat masalah kontekstual pada setiap indikator pembelajaran. Setiap pelajaran diberikan barcode scan pembelajaran yang dapat digunakan oleh siswa untuk pembelajaran online bersama orangtua di rumah. Langkah pembelajaran disusun berdasarkan perpaduan antara karakteristik dan prinsip PMRI, pendekatan saintifik, dan pemecahan masalah menurut Polya. Kurikulum 2013 menekankan pemecahan masalah menjadi satu tujuan dari belajar matematika (NCTM, 2000). Permasalahan dalam kehidupan dapat dipecahkan melalui pembelajaran PMRI (Sembiring, 2010). Uji literasi matematika oleh PISA membutuhkan kemampuan pemecahan masalah untuk menyelesaikannya (PISA, 2015).

\section{METODE}

Model pengembangan Plomp digunakan sebagai model penelitian dan Pengembangan, yakni (1) tahap penelitian awal (preliminary research), (2) tahap pengembangan protipe (prototipye phase), dan (3) tahap penilaian (assessment phase). Pemilihan model ini dengan alasan (1) model Plomp dirancang berdasarkan kebutuhan yang dimulai dengan melakukan analisis masalah, (2) model Plomp memuat kegiatan yang menghasilkan prototipe yang diharapkan mampu menghasilkan produk pengembangan dengan kualitas yang maksimal, dan (3) memiliki tahapan yang jelas dan terstruktur (Plomp \& Nieveen, 2013). Langkah-langkah pengembangan model Plomp akan disajikan pada gambar 5.

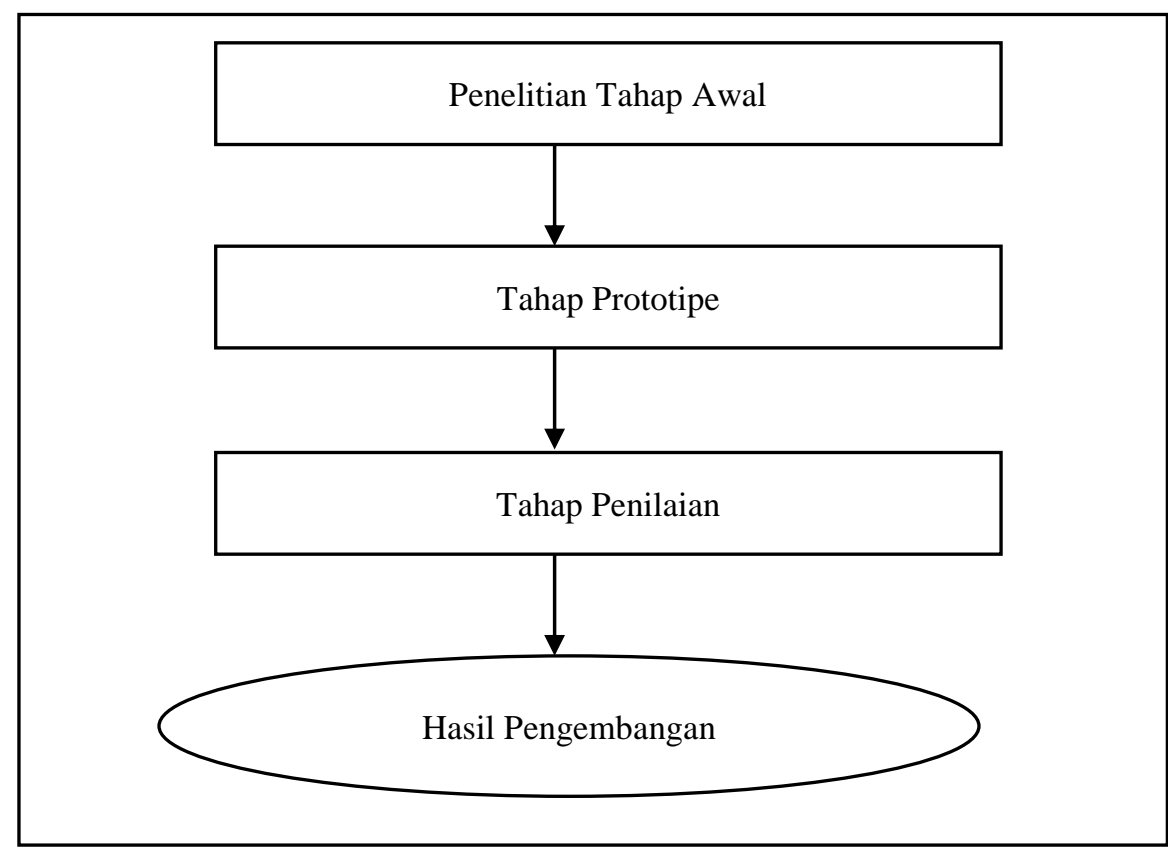

Gambar 5. Alur Pengembangan Plomp

Sumber: Plomp \& Hieveen (2013) 
Tabel 1. Fokus Langkah Pengembangan

\begin{tabular}{lll}
\hline \multicolumn{1}{c}{ Tahap } & \multicolumn{1}{c}{ Langkah dan Fokus } \\
\hline $\begin{array}{l}\text { Preliminary Research } \\
\text { (penelitian awal) }\end{array}$ & 1. & Mengidentifikasi masalah \\
& 2. & Mengidentifikasi karakteristik pembelajaran \\
& & matematika sekolah \\
& 3. & Mengkaji penggunaan bahan ajar di sekolah \\
& 4. & Mengkaji berbagai teori dan literatur \\
& 5. & Menentukan bahan yang sesuai \\
\hline Prototyping Phase & 1. & Mengembangkan materi yang telah ditentukan \\
(tahap pengembanan prototipe) & & berdasarkan kajian kurikulum 2013 revisi \\
& 2. & Mengembangkan bahan ajar dan instrumen \\
\hline Assement Phase & 1. & Validasi \& instrumen bahan ajar \\
(tahap penilaian) & 2. & Uji coba produk lapangan \\
\hline
\end{tabular}

Sumber: Adaptasi dari Plomp \& Hieveen (2013)

\section{Analisis Hasil Kevalidan}

Hasil yang diperoleh dari uji ahli dihitung menggunakan rumus. Hasil nilai persentase yang diperoleh dibadingkan sesuai kriteria tingkat kevalidan akan disajikan pada tabel 2.

Keterangan:

$$
P=\frac{\sum x}{\sum x i} \times 100 \%
$$

$$
\begin{array}{ll}
P & =\text { Hasil persentase } \\
\sum x & =\text { Hasil nilai yang diperoleh } \\
\sum x i & =\text { Hasil nilai maksimal }
\end{array}
$$

Tabel 2. Kriteria Tingkat Kevalidan

\begin{tabular}{cl}
\hline Persentase (\%) & Kriteria \\
\hline $\mathbf{8 5} \leq \boldsymbol{P}<\mathbf{1 0 0}$ & Sangat valid tanpa revisi \\
$\mathbf{7 0} \leq \boldsymbol{P}<\mathbf{8 5}$ & Valid dengan revisi kecil \\
$\mathbf{5 5} \leq \boldsymbol{P}<\mathbf{7 0}$ & Cukup valid dengan revisi kecil \\
$\mathbf{4 0} \leq \boldsymbol{P}<\mathbf{5 5}$ & Kurang valid dengan revisi besar \\
$\mathbf{1} \leq \boldsymbol{P}<\mathbf{4 0}$ & Tidak valid dan tidak dapat digunakan \\
\hline
\end{tabular}

Sumber: Adaptasi (Akbar, 2013)

\section{Analisis Hasil Kepraktisan}

Hasil yang diperoleh berdasarkan uji ahli dihitung menggunakan rumus. Hasil nilai persentase yang diperoleh dibadingkan sesuai kriteria tingkat kevalidan akan disajikan pada tabel 3.

Keterangan:

$$
P=\frac{\sum x}{\sum x i} \times 100 \%
$$

$$
\begin{array}{ll}
P & =\text { Hasil persentase } \\
\sum x & =\text { Hasil nilai yang diperoleh } \\
\sum x i & =\text { Hasil nilai maksimal }
\end{array}
$$


Tabel 3. Kriteria Tingkat Kepraktisan

\begin{tabular}{cl}
\hline Persentase (\%) & \multicolumn{1}{c}{ Kriteria } \\
\hline $\mathbf{8 5} \leq \boldsymbol{P}<\mathbf{1 0 0}$ & Sangat praktis tanpa revisi \\
$\mathbf{7 0} \leq \boldsymbol{P}<\mathbf{8 5}$ & Praktis dengan revisi kecil \\
$\mathbf{5 5} \leq \boldsymbol{P}<\mathbf{7 0}$ & Cukup praktis dengan revisi kecil \\
$\mathbf{4 0} \leq \boldsymbol{P}<\mathbf{5 5}$ & Kurang praktis dengan revisi besar \\
$\mathbf{1} \leq \boldsymbol{P}<\mathbf{4 0}$ & Tidak praktis dan tidak dapat digunakan \\
\hline
\end{tabular}

Sumber: Adaptasi dari Akbar (2013)

\section{HASIL}

\section{Hasil Tahap Penelitian Awal}

Studi pendahuluan dilakukan di SDN Sukoharjo 1 pada hari Senin, 4 November 2019, SDN Sukoharjo 2 pada hari Rabu, 6 November 2019 dan SDN Kotalama pada hari Jum'at, 8 November 2019 melalui kegiatan wawancara dengan guru kelas dan kepala sekolah, pengamatan langsung pembelajaran dikelas, telaah dokumen bahan ajar dan tes soal pemecahan masalah matematika. Hasil studi pendahuluan yang dilakukan di 3 (tiga) sekolah yakni SDN Sukoharjo 1 Kota Malang, SDN Sukoharjo 2 Kota Malang dan SDN Kota Lama 6 Kota Malang melalui pengamatan langsung proses pembelajaran dan wawancara tidak terstruktur dengan guru dan wawancara dengan kepala sekolah didapatkan informasi bahwa secara umum sekolah-sekolah tersebut memiliki kesamaan karakterisitk. Menurut Lilik Suryani, S. Pd dan kepala Sekolah SDN Sukoharjo 2 Kota Malang dari tiga sekolah tersebut didapatkan informasi bahwa di Kota Malang terdapat 6 (enam) kategori peringkat sekolah yang dibagi menjadi tiga bagian, yakni peringkat tinggi atau peringkat 1 dan 2, peringkat sedang atau peringkat 3 dan 4 , dan peringkat rendah atau peringkat 5 dan 6. Berdasarkan kategori tersebut bahwa SDN Sukoharjo 1 Kota Malang, SDN Sukoharjo 2 Kota Malang dan SDN Kota Lama 6 Kota Malang masuk dalam kategori sedang dengan peringkat ketiga dan keempat. Peringkat ini dinilai berdasarkan perolehan nilai ujian nasional dan hasil penilaian dari pengawas sekolah. Selain itu, rata-rata siswa yang terdapat di sekolah tersebut adalah siswa berasal dari luar Malang Jawa Timur yang orangtuanya bekerja dan tinggal di Malang.

Selanjutnya yakni kegiatan telaah dokumen. Hasil telaah dokumen didapatkan informasi bahwa bahan ajar yang digunakan oleh siswa kelas $\mathrm{V}$ adalah bahan ajar yang berasal dari pemerintahan pusat berdasarkan keputusan pemerintah (kemendikbud). Menurut Lilik Suryani, S. Pd sebagai guru kelas yakni guru kelas dan Dra. Heriyani, M. M sebagai kepala SDN Sukoharjo 2 Kota Malang mengungkapkan bahwa penggunaan bahan ajar bukan hanya digunakan di tiga sekolah tersebut, tetapi digunakan oleh semua sekolah yang ada di Kota Malang. Selain buku dari keputusan pemerintah, terdapat juga bahan ajar berupa modul pengayaan pembelajaran matematika yang disusun oleh tim guru dari Dinas Kota Malang. Bahan ajar yang digunakan oleh sekolah di Kota Malang berdasarkan keputusan pemerintah ditunjukan pada gambar 6, 7, dan 8.

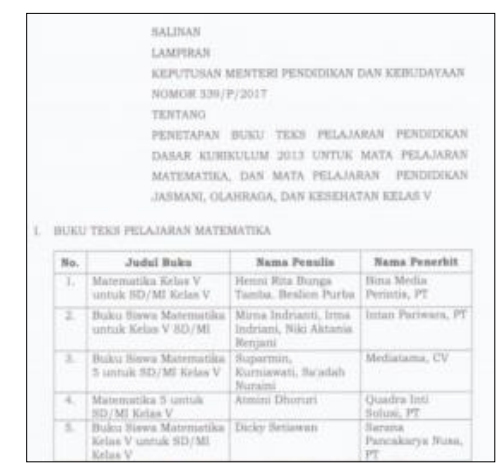

Gambar 6.

Salinan Keputusan Kemendikbud Tentang Penggunaan Buku Teks Pelajaran Matematika

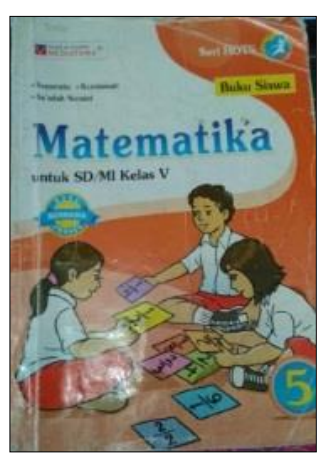

Gambar 7.

Buku Tes Pelajaran Matematika dari Kemendikbud

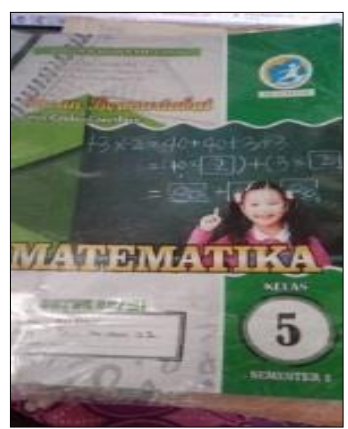

Gambar 8.

Modul Pengayaan

Pembelajaran Matematika

dari Dinas Kota Malang

Hasil analisis bahan ajar didapatkan informasi bahwa bahan ajar memiliki beberapa kelemahan. Kelemahan bahan ajar debagai berikut. Pertama, dilihat dari aspek materi bahwa bahan ajar memiliki beberapa kekurangan, seperti (a) ketidaksesuain materi yang disusun dengan stabdar kompetensi yang ditentukan dalam kurikum; (b) materi pelajaran yang disusun masih kurang mendalam; (c) masih kurang aktivitas siswa secara berkelompok, aktivitas mengkomunikasikan dan aktivitas menyimpulkan materi secara bersama sesuai dengan tuntutan pendekatan saintifik dalam kurikulum 2013; (d) masih kurang memasukan masalah konstekstual sehingga pembelajaran masih kurang bermakna bagi siswa seperti pada materi operasi 
perkalian dan pembagian pecahan; (d) materi pecahan merupakan materi yang masih banyak kekurangan dari aspek kedalaman dan keluasaan materi. Kedua, dilihat dari aspek kebahasaan (a) penggunaan kalimat dalam paragraf belum sesuai dengan tingkat perkembangan dan pemahaman siswa sehingga menyebabkan kesulitan siswa dalam memahami konsep materi pembelajaran; (b) masih terdapat beberapa ilustrasi yang panjang serta gambar yang belum jelas. Ketiga, dilihat dari aspek penyajian materi (a) materi yang disajikan belum runtut dan sulit dipahami oleh siswa sehingga menyebabkan keutuhan makna dari materi belum tersampaikan; (b) penyajian materi belum dapat mendukung kemampuan pemecahan masalah dan berpikir kreatif sesuai tingkat perkembangan siswa; (c) masih kurang mengandung wawasan kontekstual sesuai dengan ragam budaya dan karaktersitik Indonesia dan mendorong siswa menemukan sendiri makna materi untuk diterapkan dalam kehidupan keseharian. Keempat, dilihat dari aspek kegrafikan bahwa bahan ajar (a) ukuran huruf dan jenis huruf yang digunakan belum sesuai dengan usia dan karakteristik siswa; (b) belum menggunakan ilustrasi yang memperjelas pesan yang disampaikan; (c) tampilan warna pada gambar yang digunakan masih belum jelas. Selanjutnya, pada gambar adalah salah satu hasil tes soal pemecahan masalah siswa materi pecahan.

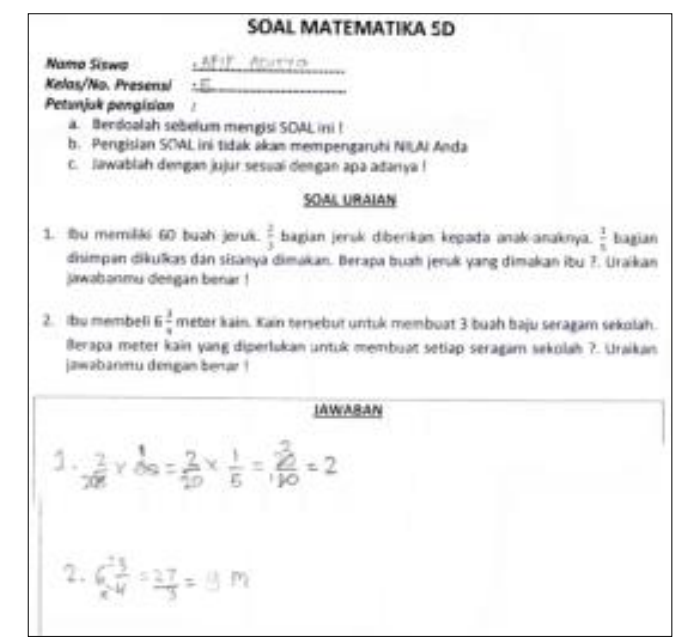

Gambar 9. Jawaban Siswa

Soal pemecahan masalah adalah soal terbuka (closed task) materi operasi hitung pecahan. Berdasarkan gambar 4 didapatkan informasi bahwa siswa belum mampu memahami masalah yang diberikan sehingga tidak mampu menentukan strategi pemecahan masalah yang akan digunakan. Hal ini menyebabkan siswa tidak dapat menyelesaikan dan menentukan kembali jawaban sesuai masalah yang diberikan. Hal ini disebabkan siswa jarang dilatih untuk menyelesaikan soal cerita pemecahan masalah. Walaupun dalam bahan ajar yang digunakan sudah terdapat soal-soal pemecahan masalah kategori soal HOTS. Namun, soal pemecahan masalah tersebut belum tepat diberikan kepada siswa usia sekolah dasar. Selain iut, kegiatankegiatan pembelajaran pada bahan ajar juga belum mendukung kemampuan pemecahan masalah matematika siswa. Hasil di atas menunjukan bahwa rendahnya kemampuan pemecahan masalah matematika siswa, salah satunya disebabkan oleh bahan ajar.

\section{Hasil Tahap Pengembangan Prototipe (prototyping phase)}

Tahap ini merupakan proses perancangan buku guru dan buku siswa berisi materi pecahan yang merupakan produk bahan ajar yang dikembangkan. Tahap ini diawali dengan mengkaji silabus, standard komptensi, kompetensi dasar dalam kurikulum kurikulum 2013 revisi 2018. Kemudian merumuskan indikator pembelajaran, membuat langkah-langkah kegiatan, dan menyusun instrumen yang akan diujikan tingkat kevalidan, kepraktisan, dan keefektifan.

\section{Tahap Penilaian (Assesment Phase)}

Tahap penilaian terdiri dari penilaian kevalidan dan penilaian kepratisan bahan ajar, RPP dan soal tes akhir. Uji kevalidan produk yakni menggunakan lembar validasi produk untuk mencapai tingkat kevalidan produk yang dikembangkan. Kemudian, penilaian kepraktisan bahan ajar (buku guru dan siswa) yang telah dikembangkan oleh pengguna bahan ajar (guru dan siswa). Berikut hasil uji kevalidan bahan ajar, soal tes akhir dan RPP disajikan pada tabel 4.

Tabel 4. Hasil Uji Kevalidan RPP dan Soal Tes Akhir

\begin{tabular}{clcc}
\hline No & Produk & Rata-Rata Persentase & Kriteria \\
\hline 1 & RPP & $79,4 \%$ & Valid dengan revisi kecil \\
2 & Soal Tes Akhir & $76,4 \%$ & Valid dengan revisi kecil \\
\hline
\end{tabular}


Pada tabel 4 diperoleh informasi bahwa rata-rata persentase kevalidan RPP sebesar 79,4\% valid dengan revisi kecil, rata-rata persentase kevalidan soal tes akhir sebesar 76,4\% valid dengan revisi kecil. Hasil tersebut menunjukkan bahwa bahan RPP dan soal akhir memenuhi kriteria valid dengan revisi kecil.

Tabel 5. Hasil Uji Kevalidan Bahan Ajar (Buku Guru dan Buku Siswa)

\begin{tabular}{cccccc}
\hline \multirow{2}{*}{ No } & \multirow{2}{*}{ Produk } & \multicolumn{2}{c}{ Uji Ahli } & \multirow{2}{*}{$\begin{array}{c}\text { Rata-Rata } \\
\text { Persentase }\end{array}$} & \multirow{2}{*}{ Kriteria } \\
\cline { 3 - 4 } & & Ahli Materi \& PMRI & Ahli Media & \\
\hline 1 & Buku Guru & $72 \%$ (Valid) & $95,4 \%$ (Valid) & $83,7 \%$ (Valid) & Valid dengan revisi kecil \\
2 & Buku Siswa & $71,7 \%$ (Valid) & $95,4 \%$ (Valid) & $83,6 \%$ (Valid) & Valid dengan revisi kecil \\
\hline \multicolumn{7}{l}{ Rata-Rata Persentase } & & $83,7 \%$ (Valid) & Valid dengan revisi kecil \\
\hline
\end{tabular}

\section{Sumber: Olahan Penulis}

Pada tabel 5 diperoleh informasi (1) rata-rata persentase kevalidan buku guru menurut ahli materi dan PMRI adalah sebesar 72\% dengan kriteria valid; (2) rata-rata persentase kevalidan buku guru menurut ahli media adalah sebesar 95,4\% dengan kriteria penilaian adalah sangat valid; (3) rata-rata persentase kevalidan buku guru menurut ahli materi dan PMRI adalah sebesar 71,7\% dengan kriteria penilaian adalah valid; (5) rata-rata persentase kevalidan buku guru menurut ahli media adalah sebesar 95,4\% dengan kriteria penilaian adalah sangat valid; (6) rata-rata persentase kevalidan buku guru menurut ahli materi \& PMRI, serta ahli media adalah sebesar 83,7\% dengan kriteria penilaian adalah valid dapat digunakan dengan revisi kecil; (7) rata-rata persentase kevalidan buku siswa menurut ahli materi \& PMRI, serta ahli media adalah sebesar 83,6\% dengan kriteria penilaian adalah valid dengan revisi kecil. Hasil tersebut menunjukkan bahwa bahan ajar berupa buku siswa dan buku guru memenuhi nilai $83,7 \%$ kriteria valid revisi kecil.

Tabel 6. Hasil Uji Kepraktisan

\begin{tabular}{|c|c|c|c|c|c|}
\hline No & Produk & Penilaian oleh Guru & Penilaian oleh Siswa & Rata-Rata Persentase & Kriteria \\
\hline 1 & Buku Guru & 94, 6\% (Sangat Praktis) & - & $94,6 \%$ & Sangat praktis tanpa revisi \\
\hline 2 & Buku Siswa & $93,8 \%$ (Sangat Praktis) & 76,7\% (Praktis) & $85,3 \%$ & Sangat praktis tanpa revisi \\
\hline \multicolumn{3}{|c|}{ Rata-Rata Persentase } & & $90 \%$ & Sangat praktis tanpa revisi \\
\hline
\end{tabular}

\section{Sumber: Olahan Penulis}

Pada tabel 6 di atas diperoleh informasi (1) rata-rata persentase kepraktisan buku guru menurut penilaian guru adalah sebesar 94,6\% dengan kriteria penilaian adalah sangat praktis; (2) rata-rata persentase kepraktisan buku siswa menurut penilaian guru adalah sebesar 93,8\% dengan kriteria penilaian adalah sangat praktis atau dapat digunakan tanpa revisi; dan (3) rata-rata persentase kepraktisan buku siswa menurut penilaian siswa adalah sebesar sebesar $76,7 \%$ dengan kriteria penilaian adalah praktis dengan revisi kecil. Hasil tersebut menunjukan bahwa bahan ajar mendapatkan nilai $90 \%$ kriteria sangat praktis tanpa revisi.

\section{PEMBAHASAN}

\section{Produk Bahan Ajar yang Telah Direvisi}

Bahan ajar yang dikembangkan disusun berdasarkan karakteristik PMRI menurut (Sembiring, 2010) yang diadaptasi dari karakteristik RME menurut Panhuizen \& Drijvers (2014). Karakteristik PMRI menurut (Sembiring, 2010), meliputi (1) adanya penggunaan konteks pada eksplorasi; (2) Menggunakan model; (3) menggunakan kreasi dan kontribusi siswa; (4) adanya interkaktivitas; (5) keterkaitan/hubungan; (6) adanya menggunakan karakteristik alam dan budaya Indonesia.

Karakteristik pertama yaitu adanya penggunaan konteks pada eksplorasi. Karakteristik ini dapat dilihat dari penggunaan masalah kontekstual pada buku siswa seperti pada kegiatan pengantar dan kegiatan ayo mengamati. Pada kegiatan pengantar dan ayo mengamati disajikan permasalah kontekstual yakni siswa diminta untuk mengamati permasalahan yang berkaitan dengan penerapan pecahan. Masalah nyata yang diberikan disesuaikan dengan masalah yang dekat dengan kehidupan dan perkembangan siswa agar masalah mampu dipahami dan dimaknai oleh siswa, serta siswa berpikir lebih mendalam dalam menyelesaikan masalah yang diberikan. Sebagaimana dinyayakan oleh Sa'diyah, dkk. (2019) bahwa siswa akan mudah memahami masalah kontekstual karena memengaruhi kinerja mereka dalam menyelesaikan masalah matematika. Selain itu, guru juga harus lebih memperhatikan bentuk dan tingkat dari masalah yang diberikan kepada siswa sehingga siswa akan memiliki lebih sedikit upaya untuk memahami masalah dan menekan pikiran siswa dalam menyelesaikan masalah.

Kemudian siswa diminta untuk merepresentasekan masalah sesuai strategi masing-masing baik respresentase gambar maupun representase simbolik, kata-kata, grafik dan lain sebagainya. Dengan adanya masalah kontekstual diharapkan pembelajaran lebih bermakna. Sebagaimana yang diungkapkan oleh (Hadi, 2017) yang menyatakan bahwa pembelajaran akan bermakna apabila dimulai dari masalah nyata dan disusun berdasarkan struktur kognitifnya dengan tujuan agar informasi baru dan struktur pengetahuan siswa dapat dihubungkan. Fatqurhohman, dkk. (2017) juga menyatakan bahwa pembelajaran akan 
bermakna apabila siswa melakukan proses penyelesaian masalah matematika secara mandiri melalui ilustrasi representase gambar menjadi respresentase simbolik. Widjaja, (2013) juga menyatakan bahwa kebermaknaan belajar dapat dilakukan melalui konteks masalah dalam kehidupan kemudian melakukan diskusi secara aktif melalui saling tukar pertanyaan untuk mengklarifikasi, memaparkan, dan memberikan kebenaran penalaran yang dilakukan. Selain itu, pembelajaran yang dimulai dari masalah konstekstual memiliki pengaruh terhadap penguatan pemahan konsep dan kemampuan pemecahan masalah siswa (Gravemeijer, 2011; Eshetu \& Assefa, 2019).

Karakterstik kedua yakni adanya penggunaan model. Penggunaan model dapat dilihat model matematika yang digunakan sebelum menyelesaikan matematika yang diberikan. Adanya penggunaan model yakni pada kegiatan ayo mencoba melalui kegiatan diskusi kelompok dan kegiatan ayo menalar. Melalui kegiatan tersebut di atas, diharapkan siswa dapat (1) mengembangkan imajinasi abstrak yang dimiliki menggunakan benda manipulatif, gambar, skema diagram atau benda konkrit untuk menjembatani kesenjangan antara konkret dengan abstraksi satu ke abstraksi yang lain; (3) berpikir kritis terhadap masalah yang dimiliki dan (4) memilih dan menerapkan strategi pemecahan masalah matematika melalui matematisasi. Sebagaimana (Saxena, Shrivastava, \& Bhardwaj, 2016) memaparkan melalui permodelan adalah kegiatan siswa dimulai dari permasalahan nyata dan kompleks serta berfokus pada kegiatan interpretasi informasi.

Bora \& Ahmed (2019) juga menyatakan bahwa dengan penggunaan model dalam pembelajaran dapat dijadikan prosedur berpikir kritis siswa dengan peristiwa kehidupan nyata atau pernyataan matematika dari suatu masalah dan proses ini memungkinkan siswa mengaitkan masalah nyata dengan matematika agar lebih bermakna dan berlangsung lama. Penggunaan model pada pembelajaran matemamatika realistik sangat diperlukan untuk menjembati menemukan konsep (Riyanto, Zulkardi., Putri, \& Darmawijoyo, 2017). Pendapat lain dari Saxena, Shrivastava, \& Bhardwaj (2016) bahwa melalui penggunaan model dalam matematika dapat membentuk pemikiran dan imajinasi abstrak yang dimiliki dengan cara yang benar, meningkatkan kreativitas memberi contoh dan cara untuk menyelesaikan masalah secara matematis dengan strategi yang tepat.

Karakterstik ketiga yakni adanya penggunaan kreasi dan kontribusi siswa. Karakteristik ketiga ini dapat dilihat dari kegiatan ayo menanya, ayo mencoba dan ayo menalar. Pada kegiatan ayo menanya terdapat pertanyaan dari guru dan siswa. Guru bertanya terhadap masalah tersebut, menstimulus dan mendorong siswa agar terlibat aktif dalam kegiatan diskusi. Sebagaimana disampaikan oleh Dahal, Luitel, \& Pant (2019) bahwa guru dapat bertanya kepada siswa dimulai dari level pertanyaan yang sederhana hingga level pertanyaan yang kompleks untuk mendorong siswa terlibat aktif dalam diskusi matematika. Siswa juga dituntut untuk mampu menjelaskan dan menguraikan lebih lanjut tentang jawaban yang benar dari pertanyaa guru dan mendorong siswa untuk mengajukan pertanyaan kembali ke guru sehingga dapat memotivasi dan tantangan bagi siswa serta lebih mengaktifkan diskusi di kelas (Shahrill, 2013).

Pada kegiatan ayo mencoba, secara berkelompok siswa dituntut untuk saling diskusi dan menjadi sarana dalam mengkonstruk konsep pada materi operasi hitung pecahan yang dipelajari melalui kegiatan matematisasi. Pada Kegiatan ayo menalar, secara mandiri siswa diberikan kesempatan bereksplorasi dan berkreativitas dalam menyelesaikan masalah yang diberikan. Sebagaimana dinyatakan oleh Daryanto (2013) bahwa konsep matematika dapat dibentuk melalui proses matematisasi. Menurut Loc \& Hao (2016) matematisasi adalah kegiatan matematika untuk mendapatkan model yang sesuai dengan masalah konteks dunia nyata. (Menon, 2013) juga menyatakan bahwa matematisasi kegiatan pengorganisasian bidang pengalaman, artinya yakni pengorganisasian level yang lebih rendah menjadi materi pelajaran di level yang lebih tinggi. Sa'dijah, dkk. (2017) menyatakan bahwa guru perlu mengetahui profil kreativitas berpikir sebelum melakukan kegiatan diskusi kelompok karena setiap siswa memiliki kreativitas masing-masing dalam menyelesaikan soal pemecahan masalah matematika.

Karakteristik keempat yakni adanya interaktivitas. Karakteristik interaktivitas dapat dilihat dari kegiatan ayo mencoba yakni kegiatan diskusi secara berkelompok untuk menyelesaikan permasalahan yang diberikan. Hal ini sependapat dengan pernyataan (Sepeng \& Webb, 2012) bahwa diskusi kelompok merupakan jembatan bagi siswa untuk saling meningkatan kompetensi dalam memecahkan masalah matematika. Kelompok dibentuk dengan tujuan untuk untuk memotivasi anggota kelompok agar saling bertanggungjawab terhadap tugas kelompoknya (Slavin, 2012).

Karakteristik kelima, keterkaitan. Keterkaitan dapat dilihat dari kegiatan ayo mencoba, ayo menalar, dan latihan soal. Pada kegiatan tersebut, materi operasi hitung pecahan dikaitkan oleh siswa dengan beberapa konsep materi lain, seperti (1) konsep penjumlahan bilangan; (2) konsep pengurangan bilangan; (3) konsep perkalian bilangan: (4) konsep pembaagian bilangan; (5) konsep KPK dan FPB; (6) konsep pembulatan bilangan. Pengaitan konsep juga dilakukan pada kegiatan pembuka yakni kegiatan apersepsi dan motivasi. Kemudian keberadaan soal latihan teka-teki silang dan soal belajar bersama orangtua diharapkan mampu mendukung kemampuan pemecahan masalah matematika siswa.

Karaktersistik keenam adalah adanya menggunakan karakteristik alam dan budaya Indonesia. Penggunaan karakteristik ini digunakan pada setiap kegiatan dalam buku siswa. Karakteristik ini perlu dimasukan karena memotivasi siswa agar lebih mengenal alam dan budaya Indonesia melalui proses pembelajaran matematika. selain itu juga, masalah yang diberikan dalam bahan ajar agar tidak jauh dari pengalaman siswa sehari-hari. Sebagaimana diungkapkan oleh (Widjaja, 2013) bahwa konteks masalah yang dekat dengan lingkungan siswa akan memberikan makna, motivasi dan minat siswa dalam belajar. Selain itu, (Sumirattana, dkk., 2017) melalui kemampuan pemecahan masalah dalam memahami peran matematika dalam kehidupan. 


\section{Kevalidan Bahan Ajar}

Rata-rata persentase hasil penilaian buku guru menurut ahli materi dan PMRI adalah $72 \%$ valid dengan revisi kecil. Rata-rata persentase hasil penilaian buku guru menurut ahli media adalah $95,4 \%$ sangat valid tanp revisi. Berdasarkan hasil penilaian ahli materi \& PMRI, serta ahli media dapat dikatakan bahwa buku guru memperoleh persentase sebesar $83,7 \%$ valid dengan revisi kecil. Sedangkan rata-rata persentase hasil penilaian buku siswa menurut ahli materi dan PMRI adalah 71,7\% valid dengan revisi kecil. Rata-rata persentase hasil penilaian buku siswa menurut ahli media adalah 95,4\% sangat valid dengan kriteria. Berdasarkan hasil penilaian ahli materi \& PMRI serta ahli media dapat dikatakan bahwa buku siswa memperoleh persentase sebesar $83,6 \%$ valid dengan revisi kecil.

Berdasarkan hasil uji kevalidan di atas dapat disimpulkan bahwa pengembangan bahan ajar (buku guru dan buku siswa) berbasis PMRI untuk mendukung kemampuan pemecahan masalah operasi hitung pecahan telah memenuhi kriteria valid dengan persentase sebesar 83,7\%. Hasil ini sesuai dengan pernyataan Sembiring (2010) bahwa bahan ajar matematika yang dikembangkan menggunakan pendekatan matematika realistik seperti buku siswa, LKS, modul, rencana pelaksananaan pembelajaran perlu divalidasi oleh ahli materi agar memperoleh tingkat kevalidan yang tinggi sehingga dapat digunakan oleh siswa serta memberikan makna dalam belajar matematika. Buku ajar bercirikan matematika realistik dapat memengaruhi kemampuan pemecahan masalah siswa dan literasi matematika (Mardiana, Sa'dijah, Qohar, \& Anwar, 2020). Selain itu, hasil penelitian yang dilakukan oleh (Ulandari, Amry, \& Saragih, 2019) bahan ajar realistik untuk meningkatkan kemampuan pemecahan masalah matematika dan self efficacy melalui uji validasi bahan ajar oleh ahli materi dengan skor akhir sebesar 4.52 yang memenuhi kriteria valid. (Waluyo, Sa'dijah, \& Subanji, 2016) dengan judul penelitian pengembangan bahan ajar berupa RPP dan LKPD berbasis realistic mathematics education memperoleh skor 3,22 yang memenuhi kriteria valid untuk RPP dan skor 3,21 kriteria valid untuk LKPD.

\section{Kepraktisan Bahan Ajar}

Rata-rata uji kepraktisan buku guru oleh penilaian guru adalah 94,6\% sangat praktis tanpa revisi. Sedangkan rata-rata uji kepraktisan buku siswa oleh guru adalah 93,8\% sangat praktis tanpa revisi. Rata-rata persentase uji kepraktisan buku siswa oleh siswa adalah 76,7\% valid dengan revisi kecil. Oleh sebab itu, bahan ajar (buku guru dan buku siswa) memperoleh persentase sebesar 90\% sangat praktis tanpa revisi. Berdasarkan hasil di atas dapat disimpulkan bahwa pengembangan bahan ajar berbasis PMRI) untuk mendukung kemampuan pemecahan masalah operasi hitung pecahan memperoleh kriteria praktis sebesar 90,2\%. Hasil ini sesuai dengan penelitian yang dilakukan oleh (Waluyo, Sa'dijah, \& Subanji, 2016) yang mengembangkan bahan ajar berupa RPP dan LKPD memenuhi kriteria kepraktisan. Mardiana, Sa'dijah, Qohar, \& Anwar (2020) yang mengembangkan bahan ajar bercirikan matematika realistik akan dapat mendukung kemampuan literasi matematika siswa sekolah menengah pertama dan hasil analisis menunjukkan kriteria yang sangat praktis. Selain itu, penelitian yang dilakukan oleh (Khusna, Yuwono, \& Muksar, 2016) yang mengembangkan LKS RME memperoleh nilai 3,5 praktis tanpa direvisi.

Berdasarkan hasil uji kevalidan dan uji kepraktisan tersebut bahwa bahan ajar (buku guru dan buku siswa) berbasis Pendidikan Matematika Realistik Indonesia (PMRI) untuk mendukung kemampuan pemecahan masalah operasi hitung pecahan memenuhi kriteria valid dan praktis.

\section{SIMPULAN}

Berdasarkan uji kevalidan dapat disimpulkan bahwa bahan ajar (buku guru dan buku siswa) memenuhi kriteria valid dengan persentase sebesar 83,7\%, RPP sebesar 79,4\% valid dan soal tes akhir 76,4\% valid dengan kriteria valid. Hasil uji kepraktisan bahan ajar dapat disimpulkan bahan ajar (buku guru dan buku siswa) memenuhi kriteria sangat praktis dengan persentase sebesar $90 \%$. Berdasarkan hasil uji kevalidan dan uji kepraktisan tersebut dapat disimpulkan bahwa bahan ajar berbasis Pendidikan Matematika Realistik Indonesia (PMRI) untuk mendukung kemampuan pemecahan masalah operasi hitung pecahan memenuhi kriteria valid dan praktis.

Ada beberapa saran dari peneliti untuk perbaikan produk antara lain: (1) produk diharapkan mampu sebagai bahan ajar alternatif; (2) menjadi alternative untuk mengembangkan bahan ajar serupa; (3) melakukan uji efektivitas untuk peneliti selanjutnya; (4) penyajian materi dan soal dalam bahan ajar perlu disesuaikan dengan karakteristik dan perkembangan siswa; (5) menggunakan masalah kontekstual yang memiliki karakteristik alam dan sesuai budaya Indonesia agar pembelajaran lebih bermakna dan meningkatkan minat dan motivasi siswa dalam belajar.

\section{DAFTAR RUJUKAN}

Ahyansyah. (2019). Kemampuan Literasi Matematika Siswa Sekolah Dasar Ditinjau Dari Gaya Belajar. Prosiding Seminar Nasional Lembaga Penelitian dan Pendidikan (LPP) Mandala, 78-87.

Akbar, S. (2013). Instrumen Perangkat Pembelajaran. Bandung: Remaja Rosdakarya.

Asih, A. K., Irawan, E. B., \& Sa'dijah, C. (2018). Penerapan Realistic Mathematics Education untuk Meningkatkan Kemampuan Pemecahan Masalah Matematika di Sekolah Dasar. Jurnal Pendidikan: Teori, Penelitian, dan Pengembangan, 2(4), 1512-1519. 
Bora, A., \& Ahmed, S. (2019). Mathematical Modeling: An Important Tool for Mathematics Teaching. International Journal of Research and Analytical Reviews (IJRAR), 6(2), 252-256.

Dahal, N., Luitel, B. C., \& Pant, B. P. (2019). Understanding the Use of Questioning by Mathematics Teachers: A Revelation. International Journal of Innovation, Creativity and Change, 5(1), 118-146.

Daryanto. (2013). Inovasi Pembelajaran Efektif. Bandung: Yrama Widya.

Eshetu, F., \& Assefa, S. (2019). Effects of Context-Based Instructional Approaches on Students' Problem-Solving Skills in Rotational Motion. Eurasia Journal of Mathematics, Science and Technology Education, 15(2). https://doi.org/10.29333/ejmste/102283.

Fatqurhohman, Sa'dijah, C., Irawan, E. B., \& Sulandra, I. M. (2017). Representation of Secondary School Students in Solving Fractions. International Journal of Innovation in Science and Mathematics, 5(6), 172-176.

Gravemeijer, K. (2011). How Concrete is Concrete?. Journal on Mathematics Education, 2(1), 1-14. https://doi.org/10.22342/jme.2.1.780.1-14

Hasibuan, A. M., Saragih, S., \& Amry, Z. (2018). Development of Learning Materials Based on Realistic Mathematics Education to Improve Problem Solving Ability and Student Learning Independence. International Electronic Journal of Mathematics Education, 14(1), 243-252. https://doi.org/10.29333/iejme/4000

Hasnawati. (2016). Description of Mathematics Literacy Ability of Students First Secondary School State 15 Kendari Based on Content, Context, Materials, and Process. International Journal of Education and Research, 4(11), 201-210.

Khusna, A. H., Yuwono, I., \& Muksar, M. (2016). Pengembangan Lembar Kerja Siswa (LKS) Berkarakteristik RME Materi Barisan dan Deret untuk Kelas X. Jurnal Pendidikan: Teori, Penelitian, dan Pengembangan, 1(4), 739-745.

Koparan, T. (2017). Analysis of Teaching Materials Developed by Prospective Mathematics Teachers and Their Views on Material Development. Malaysian Online Journal of Educational Technology, 5(4), 8-28.

Loc, N. P., \& Hao, M. H. (2016). Teaching Mathematics Based on "Mathematization " of Theory of Realistic Mathematics Education : A Study of the Linear Function $\mathrm{Y}=\mathrm{Ax}+\mathrm{B}$. The International Journal of Engineering And Science (IJES), $5(6), 20-23$.

Mahdiansyah., \& Rahmawati. (2014). Literasi Matematika Siswa Pendidikan Menengah: Analisis menggunakan Desain Tes Internasional dengan Konteks Indonesia. Jurnal Pendidikan dan Kebudayaan, 20(4), 452-469. https://doi.org/10.24832/jpnk.v20i4.158

Manopo., Sudirman., \& Sulandra, I. M. (2018). Pengembangan Bahan Ajar Materi Perbandingan Bercirikan Realistic Mathematics Education. Jurnal Pendidikan: Teori, Penelitian, dan Pengembangan, 3(5), 693-699.

Maulydia, S. S., Surya, E., \& Syahputra, E. (2017). The Development of Mathematic Teaching Material Through The Development of Mathematic Teaching Material Through Realistic Mathematics Education to Increase Mathematical Problem Solving. International Journal of Advance Research And Innovative Ideas in Education, 3(2), $2965-2971$.

Mardiana, E., Sa'dijah, C., Qohar, A., \& Anwar, L. (2020). Practicalitya and Effectiveness of Realistic Mathematical Learning Materials to Support Mathematical Literacy Skill of Junior High School Students. 2215. AIP Conference Proceedings. DOI: https://doi.org/10.1063/5.0000844.

Ojose, B. (2011). Mathematics Literacy: Are We Able to Put The Mathematics We Learn into Everyday Use? Journal of Mathematics Education, 4(1), 89-100.

Prianto, A., Sulandra, I. M., \& Subanji. (2016). Berpikir Kreatif Dalam Pembelajaran RME. Jurnal Pendidikan: Teori, Penelitian, dan Pengembangan, 1(7), 1442-1448.

Riyanto, B., Zulkardi., Putri, R. I. I., \& Darmawijoyo. (2017). Mathematical Modeling in Realistic Mathematics Education. Journal of Physics: Conference Series, 943(1), 1-7. https://doi.org/10.1088/1742-6596/943/1/012049

Sa'dijah, C. (2013). Kepekaan Bilangan Siswa SMP melalui Pembelajaran Matematika Kontekstual yang Mengintegrasikan Keterampilan Berpikir Kreatif. Jurnal Pendidikan dan Pembelajaran, 20(2), 222-227.

Sa'dijah, C., Yuwono, I., \& Anwar, L. (2013). Pengembangan Model Pembelajaran Kontekstual yang Mengintegrasikan Karakter Berpikir dan Mendukung Kepekaan Bilangan (Number Sense). In Pengembangan Model Pembelajaran Kontekstual yang Mengintegrasikan Karakter Berpikir dan Mendukung Kepekaan Bilangan (Number Sense). Penelitian tidak diterbitkan.

Sa'dijah, C., Sa'diyah, M., Sisworo, \& Anwar, L. (2020). Students' Mathematical Dispositions Towards Solving HOTS Problems Based on FI and FD Cognitive Style. 2215. AIP Conference Proceedings. DOI: https://doi.org/10.1063/5.0000644.

Sa'dijah, C., Handayani, U. F., Sisworo, Sudirman, Susiswo, Cahyowati, E. T., et al. (2019). The Profile of Junior High School Students' Mathematical Creative Thinking Skills in Solving Problem through Contextual Teaching. Journal of Physics: Conference Series, 1-15. DOI: doi:10.1088/1742-6596/1397/1/012081.

Sa'diyah, M., Sa'dijah, C., Sisworo, \& Handayani, U. F. (2019). How Students Build Their Mathematical Dispositions towards Solving Contextual and Abstract Mathematics Problems. Journal of Physics: Conference Series, 1-10.DOI: doi:10.1088/1742-6596/1397/1/012090.

Saxena, R., Shrivastava, K., \& Bhardwaj, R. (2016). Teaching mathematical Modeling in School Mathematics. Journal of Education and Practice, 7(11), 34-44. 
Sembiring, R. K. (2010). Pendidikan Matematika Realistik Indonesia (PMRI): Perkembangan dan tantangannya. Journal on Mathematics Education, 1(1), 11-16. https://doi.org/10.22342/jme.1.1.791.11-16

Sepeng, P., \& Webb, P. (2012). Exploring Mathematical Discussion in Word Problem Solving. Pythagoras, 33(1), 1-8. https://doi.org/10.4102/pythagoras.v33i1.60

Shahrill, M. (2013). Review of Effective Teacher Questioning in Mathematics Classrooms. International Journal of Humanities and Social Science, 3(17), 224-231.

Soedjadi, R. (2014). Inti Dasar-Dasar Pendidikan Matematika Realistik Indonesia. Jurnal Pendidikan Matematika, 1(2), 1-10. https://doi.org/10.22342/jpm.1.2.807.

Stacey, K. (2010). Mathematical and scientific Literacy Around the world. Journal of Science and Mathematics Education in Southeast Asia, 33(1), 1-16.

Sumirattana, S., Makanong, A., \& Thipkong, S. (2017). Using Realistic Mathematics Education and the DAPIC ProblemSolving Process to Enhance Secondary School Students' Mathematical Literacy. Kasetsart Journal of Social Sciences, 38(3), 307-315. https://doi.org/10.1016/j.kjss.2016.06.001

Ubaidillah, M. F., Subanji, \& Sa'dijah, C. (2014). Bahan Ajar Berbasis Realistic Mathematic Education (RME) Materi Opersi Hitung untuk Siswa Sekolah Dasar.

Ulandari, L., Amry, Z., \& Saragih, S. (2019). Development of Learning Materials Based on Realistic Mathematics Education Approach to Improve Students' Mathematical Problem Solving Ability and Self-Efficacy. International Electronic Journal of Mathematics Education, 14(2), 375-383. https://doi.org/10.29333/iejme/5729

Waluyo, E., Sa'dijah, C., \& Subanji. (2016). Pengembangan RPP dan LKPD Berbasis Realistic Mathematics Education dengan Memerhatikan Beban Kognitif Siswa Materi Bangun Ruang Sederhana Kelas IV SD. Jurnal Pendidikan: Teori, Penelitian, dan Pengembangan, 1(12), 2300-2306.

Widjaja, W. (2013). The Use of Contextual Problems to Support Mathematical Learning. Journal on Mathematics Education, 4(2), 151-159. https://doi.org/10.22342/jme.4.2.413.151-159

Wilkens, H. J. (2011). Textbook approval Systems and the Program for International Assessment (PISA) Results: A Preliminary Analysis. IARTEM e - Journal, 4(2), 63-74. 